\title{
Fetal myelomeningocele repair: where are we and where can we go?
}

\author{
Cirurgia fetal para meningomielocele: \\ onde nós estamos e aonde podemos ir?
}

Spina bifida is one of the most prevalent major birth malformations with a worldwide incidence of approximately 1:2,000 live births ${ }^{1}$. A myelomeningocele (MMC) is the most frequent form of spina bifida, characterized by the extrusion of the spinal cord and/or nerves through a bony defect of the spine into a sac filled with cerebrospinal fluid (CSF). The severity of symptoms is correlated with the level of the defect. Interruption of the spinal cord at the site of the defect can cause lifelong paralysis of the legs, bowel and bladder dysfunction, sensibility disorders of the skin, sexual dysfunction and deformation of the lower extremities and back. Most children with spina bifida are not mentally retarded, but their intelligence quotient can be reduced ${ }^{2,3}$. Although spina bifida can be compatible with independent life, lifelong supportive care is often needed, and only about half of the patients are able to live independently as adults, even with adapted accommodations ${ }^{3,4}$. The majority of children with spina bifida have a Chiari II malformation, which is a combination of hindbrain herniation and hydrocephalus ${ }^{4}$, and is the leading cause of death in patients with spina bifida ${ }^{5}$. In $45 \%$ of the fetuses with spina bifida registered within the Dutch registration of Eurocat, the parents decided to terminate pregnancy after prenatal diagnosis. This is consistent with numbers from the USA; however, in some areas of the Netherlands, these figures are considerably higher ${ }^{2}$.

With the introduction of the routine second trimester ultrasound scan, the number of prenatal diagnosis of spina bifida increased considerably. The classical prenatal ultrasound findings in spina bifida are typical U-shaped defect of the vertebral column in an open spina bifida, typical lemon shape of the fetal skull and banana shape of cerebellum. The ventriculomegaly occurs in the majority of cases, and club feet are also present in several cases ${ }^{6}$. The current standard of postnatal care is neurosurgical closure of the defect within 48 to 72 hours after birth. However, surgical intervention does not improve neurological function, but prevents further deterioration ${ }^{7}$. After birth, 80 to $90 \%$ of children with hydrocephalys will receive a ventriculo-peritoneal shunt placement to prevent additional damage to brain and brainstem ${ }^{8}$. Despite the successes of postnatal neurosurgical repair and medical treatment of spina bifida, mortality still remains approximately $10 \%$, rising to $35 \%$ in those children with symptoms of brainstem dysfunction secondary to the Chiari II malformation.

Department of Obstetrics and Fetal Therapy, Leiden University Medical Center - Leiden, The Netherlands. 'Department of Obstetrics, Escola Paulista de Medicina, Universidade Federal de São Paulo - UNIFESP - São Paulo (SP), Brasil. ${ }^{2}$ Department of Obstetrics and Fetal Therapy, Leiden University Medical Center - Leiden, The Netherlands. ${ }^{3}$ Department of Obstetrics and Gynecology, Erasmus MC, University Medical Center Rotterdam - Rotterdam, The Netherlands. Conflict of interests: none. 
The question whether the neurological disorders associated with spina bifida are caused by either a primary disorder of neurulation during the embryonic development of the spinal cord, or by secondary damage to a primarily normal spinal cord caused by the intrauterine environment, or both, has been studied and described extensively in the literature ${ }^{9,10}$. This knowledge led to the "two-hit" hypothesis: failure of primary neurulation in the embryonic period leads to the development of myelodysplasia (first-hit), and, due to the absence of skin and musculoskeletal coverage, the persistent exposure of the openly exposed neural tissue to the intrauterine environment can lead to secondary acquired neural tissue damage and, consequently, irreversible loss of neurological function (second-hit) ${ }^{11,12}$. Experiments suggest that late gestation amniotic fluid might be toxic to the exposed neural tissue and can cause chemical injury ${ }^{13}$. Destruction can also be caused by mechanical shearing and abrasive stresses on the surface of the delicate neural tissue, especially in the third trimester, when there is increasingly less amniotic fluid ${ }^{11}$.

This "two-hit" hypothesis is the rationale for in utero repair of a spina bifida, implicating that the second hit can be prevented by intrauterine closure of the defect ${ }^{12}$. Prenatal coverage would stop the progressive neural tissue destruction and improve the neurological outcome at birth ${ }^{14}$. Also, in utero coverage of the defect may stop the leakage of CSF and consequently have a positive effect on the associated cerebral anomalies like hindbrain herniation and hydrocephalus ${ }^{15}$.

The first intrauterine MMC repairs were performed in mid-1990s using the endoscopic technique in the Vanderbilt University Medical Center, Nashville, Tennessee, USA; however, the technique was abandoned because of bad outcomes ${ }^{16}$. The first open surgeries for intrauterine treatment of MMC were performed in the end-1990s, and the outcome of children after prenatal surgery showed decreased rate of ventriculo-peritoneal shunt placement and reversion of brainstem herniation when compared with postnatal surgery ${ }^{17,18}$. However, the rates of complications as preterm labor, premature rupture of membranes, preterm delivery, choriomnionites, uterine dehiscence and perinatal deaths still were considerable ${ }^{19,20}$. Because of controversies between benefits versus risks of intrauterine MMC repair, a randomized controlled trial, named Management of Myelomeningocele Study (MOMS), was developed between 2003 and 2008 in three American centers (University of California, The Children's Hospital of Philadelphia and Vanderbilt University Medical Center). This trial proposed to randomize 200 pregnant women, being 100 to intrauterine repair and 100 to postnatal surgery. The trial stopped after the recruitment of 183 patients, because of the benefits of intrauterine surgery. Intrauterine MMC repair reduced the rate of ventriculo-peritoneal shunt placement, showed improvements in a composite score for mental development and motor function at 30 months and improvements in several secondary outcomes, including hindbrain herniation by 12 months and ambulation by 30 months. However, open surgery was still associated with maternal and fetal risks, mainly uterine dehiscence and preterm deliveries ${ }^{21}$. After this trial, the participating centers published their own post-MOMS trial experience with better outcomes, mainly in uterine dehiscence and premature rupture of membranes rates ${ }^{22,23}$. From other centers in the world, only limited data is available with small numbers of cases ${ }^{24,25}$.

In 2000s, the endoscopic technique was restarted in two centers, one in Germany and one in Brazil ${ }^{26,27}$. The first cases were published recently, however not within a randomized controlled trial to prove its real benefits. Compared to open surgery, the endoscopic technique takes a longer duration time of surgery and has a higher rate of premature rupture of membranes. In some cases, a second surgery is necessary after birth to correct the spinal defect. Especially with large defects primarily, tension-free, in utero closure with skin is sometimes not possible ${ }^{28}$.

Because of the present outcomes after endoscopic surgery and also the high rate of premature rupture of membranes and preterm labor, further research is warranted. Single port access with an endoscope of $3.0 \mathrm{~mm}$ or less and covering the defect using smart tissue engineering techniques might decrease the complication rate and allow normal delivery instead of cesarean section. Tissue engineered constructs or glues need to be tailored, especially to the needs of surgical reconstruction of birth defects in the fetal period, particular when looking at the prerequisites of fetal MMC surgery.

\section{References}

1. Walsh DS, Adzick NS. Foetal surgery for spina bifida. Semin Neonatol. 2003;8(3):197-205.

2. Sutton $L N$. Fetal surgery for neural tube defects. Best Pract Res Clin Obstet Gynaecol. 2008;22(1):175-88.

3. Bruner JP, Tulipan N. Tell the truth about spina bifida. Ultrasound Obstet Gynecol. 2004;24(6):595-6.
4. Wagner W, Schwarz M, Perneczky A. Primary myelomeningocele closure and consequences. Curr Opin Urol. 2002;12(6):465-8.

5. Sutton LN, Adzick NS, Bilaniuk LT, Johnson MP, Crombleholme TM, Flake AW. Improvement in hindbrain herniation demonstrated by serial fetal magnetic resonance imaging following fetal surgery for myelomeningocele. JAMA. 1999;282(19):1826-31. 
6. Nicolaides KH, Campbell S, Gabbe SG, Guidetti R. Ultrasound screening for spina bifida: cranial and cerebellar signs. Lancet. 1986;2(8498):72-4.

7. Olutoye OO, Adzick NS. Fetal surgery for myelomeningocele. Semin Perinatol. 1999;23(6):462-73.

8. Babcook CJ, Goldstein RB, Barth RA, Damato NM, Callen PW, Filly RA. Prevalence of ventriculomegaly in association with myelomeningocele: correlation with gestational age and severity of posterior fossa deformity. Radiology. 1994;190(3):703-7.

9. Paek BW, Farmer DL, Wilkinson CC, Albanese CT, Peacock W, Harrison MR, et al. Hindbrain herniation develops in surgically created myelomeningocele but is absent after repair in fetal lambs. Am J Obstet Gynecol. 2000; 183(5): 111 19-23.

10. Meuli M, Meuli-Simmen C, Hutchins GM, Seller M, Harrison MR, Adzick NS. The spinal cord lesion in human fetuses with myelomeningocele: implications for fetal surgery. J Pediatr Surg. 1997;32(3):448-52.

11. Drewek M, Bruner JP, Whetsell WO, Tulipan N. Quantitative analysis of the toxicity of human amniotic fluid to cultured rat spinal cord. Pediatr Neurosurg. 1997;27(4):190-3.

12. Walsh DS, Adzick NS, Sutton LN, Johnson MP. The rationale for in utero repair of myelomeningocele. Fetal Diagn Ther. 2001; 16(5):312-22.

13. Meuli M, Meuli-Simmen C, Hutchins GM, Yingling CD, Hoffman KM, Harrison MR, et al. In utero surgery rescues neurological function at birth in sheep with spina bifida. Nat Med. 1995; 1 (4):342-7.

14. Adzick NS. Fetal myelomeningocele: natural history, pathophysiology, and in-utero intervention. Semin Fetal Neonatal Med. 2010;15(1):9-14.

15. Tulipan N, Hernanz-Schulman M, Bruner JP. Reduced hindbrain herniation after intrauterine myelomeningocele repair: a report of four cases. Pediatr Neurosurg. 1998;29(5):274-8.

16. Bruner JP, Richards WO, Tulipan NB, Arney TL. Endoscopic coverage of fetal myelomeningocele in utero. Am J Obstet Gynecol. 1999; 180(1 Pt 1):153-8.

17. Bruner JP, Tulipan N, Paschall RL, Boehm FH, Walsh WF, Silva SR, et al. Fetal surgery for myelomeningocele and the incidence of shunt-dependent hydrocephalus. JAMA. 1999;282(19): $1819-25$.

18. Tulipan N, Bruner JP, Hernanz-Schulman M, Lowe LH, Walsh WF, Nickolaus D, et al. Effect of intrauterine myelomeningocele repair on central nervous system structure and function. Pediatr Neurosurg. 1999;31(4):183-8.
19. Johnson MP, Sutton LN, Rintoul N, Crombleholme TM, Flake AW, Howell $\amalg$, et al. Fetal myelomeningocele repair: short-term clinical outcomes. Am J Obstet Gynecol. 2003;189(2):482-7.

20. Farmer DL, von Koch CS, Peacock WJ, Danielpour M, Gupta N, Lee $\mathrm{H}$, et al. In utero repair of myelomeningocele: experimental pathophysiology, initial clinical experience, and outcomes. Arch Surg. 2003;138(8):872-8.

21. Adzick NS, Thom EA, Spong CY, Brock JW 3rd, Burrows PK, Johnson MP, et al. A randomized trial of prenatal versus postnatal repair of myelomeningocele. N Engl J Med. 2011; 364(1 1):993-1004.

22. Bennett KA, Carroll MA, Shannon CN, Braun SA, Dabrowiak $M E$, Crum AK, et al. Reducing perinatal complications and preterm delivery for patients undergoing in utero closure of fetal myelomeningocele: further modifications to the multidisciplinary surgical technique. J Neurosurg Pediatr. 2014;14(1):108-14.

23. Moldenhaver JS, Soni S, Rintoul NE, Spinner SS, Khalek N, Martinez-Poyer J, et al. Fetal myelomeningocele repair: the postMOMS experience at the Children's Hospital of Philadelphia. Fetal Diagn Ther. 2015;37(3):235-40.

24. Marenco ML, Márquez J, Ontanilla A, García-Díaz L, Rivero M, Losada A, et al. [Intrauterine myelomeningocele repair: experience of the fetal medicine and therapy program of the Virgen de Rocío University Hospital]. Rev Esp Anestesiol Reanim. 2013;60(1):4753. Spanish.

25. Meuli $M$, Moehrlen U, Flake A, Ochsenbein N, Huesler $M$, Biro $P$, et al. Fetal surgery in Zurich: key features of our first open in utero repair of myelomeningocele. Eur J Pediatr Surg. 2013;23(6):494-8.

26. Degenhardt J, Schürg R, Winarno A, Oehmke F, Khaleeva A, Kawecki $A$, et al. Percutaneous minimal-access fetoscopic surgery for spina bifida aperta. Part Il: maternal management and outcome. Ultrasound Obstet Gynecol. 2014;44(5):525-31.

27. Pedreira DA, Zanon N, Sá RA, Acacio GL, Ogeda E, Belem TM, et al. Fetoscopic single-layer repair of open spina bifida using a cellulose patch: preliminary clinical experience. J Matern Fetal Neonatal Med. 2014;27(16):1613-9.

28. Graf K, Kohl T, Neubauer BA, Dey F, Faas D, Wanis FA, et al. Percutaneous minimally-invasive fetoscopic surgery for spina bifida aperta - Part III - Postnatal neurosurgical interventions in the first year of life. Ultrasound Obstet Gynecol. 2015 Jul 3. [Epub ahead of print]. 